Raportti

\title{
Matkakirjeitä Uudesta Maasta
}

\author{
Akseli Virratvuori
}

$\mathrm{T}$ yypillisiä syitä lähteä opiskelemaan ulkomaille ovat mahdollisuus tutustua uuteen kulttuuriin, kansainvälinen verkostoituminen, ansioluettelon lihottaminen, yleinen ihmisenä kasvaminen tai niin sanottu "itsensä löytäminen". Ajatus ulkomaille lähdöstä alkoi itää vuoden 2017 kesällä, jolloin vierailin Prahassa keräämässä aineistoa suomalaista kannabiksen kulutusta koskevaa pro gradu -tutkielmaani (Virratvuori 2018) varten. Visiittini aikana ihastuin muinaisen ja eri ismien vuorotellen runteleman kaupungin seksikkääseen rosoiseen energiaan, jonka rinnalla koto-Suomi alkoi tuntua turhan tutulta ja turvalliselta. Alhaisesta hinnastaan huolimatta erinomaisen paikallisen oluen ohessa haastateltavani mainitsi Kanadan yhtenä mahdollisista tulevaisuuden asuinpaikoistaan. Niin, Kanada, miksipä ei? Käsittääkseni kyseessä oli olemukseltaan melko pohjoismainen ja suhteellisen hyvinvoiva valtio, joka erottuu useimmilla hyvinvoinnin mittapuilla edukseen, etenkin verrattaessa eteläiseen naapuriinsa. Tämän lisäksi ajatus jylhistä maisemista ja matalasta väestöntiheydestä viehätti minua kovin. Pahimmassakin tapauksessa ne paikalliset, joiden kanssa joutuisi olemaan tekemisissä, olisivat toivottavasti stereotyyppisen kohteliaita. Poikamaisen karismaattisen ja komean, mutta korruptioepäilysten tahraaman pääministeri Justin Trudeaun luotsaama liberaalipuolue oli ennen valtaannousuaan luvannut laillistaa kannabiksen kulutuksen ja luoda sen ympärille valtion valvomat markkinat vuoden 2018 loppupuolella. Koska olin päättänyt, että huumeet ja huumekulttuuri olivat minun aihepiirini folkloristina, jatko-opiskelu Kanadassa vaikutti loogiselta valinnalta myös orastavien urasuunnitelmieni kannalta. Sen sijaan että jatkaisin aiheen parissa Suomessa, jossa verrattain jäykkä huumepolitiikka ikävä kyllä hankaa kehitystä vastaan, voisin hankkia Kanadassa asiantuntemusta liittyen kieltolain loppumiseen, sen haasteisiin ja etenkin kulttuurivaikutuksiin. Kannabiksen väistämättä laillistuessa laajemmin voisin kaupata hankkimaani asiantuntemusta ympäri maailmaa, joko kansalaisaktivistin tai opportunistin roolissa.

\section{Ennen lähtöä}

Googlatessani potentiaalisia kanadalaisia yliopistoja hakusanat Canada + Folklore + University tuottivat vain kaksi tulosta: Quebecin provinssissa sijaitsevan ranskankielisen Lavalin yliopiston sekä Memorial University of Newfoundlandin, lyhennettynä MUN. Koska je ne parle pas français, oli valinta varsin yksinkertainen. En tiennyt Newfoundlandista mitään, mutta Googlen kuvahaun mukaan provinssi vaikutti varsin romanttiselta jylhine rantakallioineen ja sateenkaaren värein maalattuine rivitaloineen. Olin nuorempana viettänyt jonkin verran aikaa Britteinsaarilla ja mieltynyt alueen melankoliseen rannikkoon ja ikuisen kasteen 
peittämiin nummiin. Oletin, että Newfoundland olisi Atlantin toispuolisesta sijainnistaan huolimatta pitkälti verrattavissa tähän itselleni tuttuun ympäristöön, onhan saari sentään Pohjois-Amerikassa Eurooppaa ja Irlannin rannikkoa lähimpänä oleva piste. Välimatkaa on kolmisen tuhatta kilometriä. Suunnitelmani toteutuminen onnistuneesti oli nyt kiinni useammasta muuttujasta. Ensimmäinen kysymysmerkki oli graduni valmistuminen ja tutkintoni loppuun saattaminen ennen hakuajan umpeutumista. Jos joutuisin odottamaan vuoden, olisin auttamattomasti jälkijunassa kannabiksen laillistumisen dokumentoinnin suhteen. Linnoittauduin turkulaiseen opiskelija-asuntooni useammaksi kuukaudeksi, ja maanisen työrupeaman lopputuloksena oli Arnold van Gennepin ja Victor Turnerin siirtymäriitteihin ja liminaalisuuteen liittyviä ajatuksia suomalaiseen kannabiksen kulutukseen soveltava pro gradu -tutkielma. Kelan opintotuen loppumisesta ilmoittava kirje tippui postiluukusta kirjaimellisesti samalla hetkellä, kun lähetin työn lopullisen version arvioitavaksi.

Olin pysynyt aikataulussani ja ehdin lähettää hakemukseni Memorial Universityyn hyvissä ajoin. Kuukausia kestäneen epätietoisuuden jälkeen sain myöntävän vastauksen. Itkin ja soitin äidille. Olin onnellinen, koska tiesin taas mitä tulisin tekemään muutaman vuoden eteenpäin, harvinaista luksusta 1990-luvulla syntyneelle. Iloa seurasi puoli vuotta vieraaseen valtioon muuttamiseen liittyvää stressiä ja huolta. Vaikeinta oli hyvästellä yksi kerrallaan jokainen Suomessa muodostamani ihmissuhde vähintään neljäksi vuodeksi, lukuun ottamatta sähköistä yhteydenpitoa ja ajoittaisia visiittejä Suomeen. Tämän lisäksi huomattava kynnyskysymys oli tulevien opintojen rahoittaminen. Opintopaikka toi mukanaan 11,000 dollarin vuosittaisen rahoituspaketin yhteensä neljän vuoden ajaksi, joka hädin tuskin riittää lukukausimaksujen ja vuokran maksuun, muista tarpeista puhumattakaan. Hintatasonsa suhteen Memorial University on Kanadan halvin, vaikkakin ulkomaalainen opiskelija saakin osakseen kaksinkertaisen lukukausimaksun verrattuna paikalliseen. Kun myöhemmin mainitsen, etten ole maksanut penniäkään kandidaatin tai maisterin tutkinnosta, puhumattakaan opiskelijaravintoloiden huokeista hinnoista, on reaktio usein epäusko. Monelle opiskelijalle, etenkin ulkomaalaiselle, opintojen rahoittaminen tarkoittaa huonopalkkaista osa-aikaista työtä pikaruokaloissa ja kauppakeskuksissa. Moni etenkin Lähi-Idästä ja Aasiasta tuleva opiskelija vaikuttaa toivovan paikallisen tutkinnon mahdollisesti suomaa pysyvämpää oleskelulupaa. Newfoundlandin ja Labradorin väestö vanhenee nuorison muuttaessa mantereelle työn perässä ja provinssi tarvitsee uutta verta, joten maahanmuutto palvelee kaikkia osapuolia. Olen itse onnistunut kahmimaan itselleni useita pitkiä ja lyhyempiä työpestejä yliopiston sisällä, mikä on mahdollistanut jonkinasteisen joustavuuden omien opintojen suhteen.

\section{Nationalismi ja folklore, vanhat petikaverit}

Memorial University ja sen folkloristiikan oppiaine saivat molemmat alkunsa osana Newfoundlandin ja Labradorin provinssin liittymistä osaksi muuta Kanadaa 1948. Provinssin tuolloinen pääministeri Joey Smallwood oli kiihkeä ja kiistanalainen nationalisti, joka koki Newfoundlandin kulttuuri-identiteetin dokumentoinnin tarjoavan vastapainoa konfederaation aiheuttamalle autonomian menetykselle. Tässä kohtaa lienee syytä mainita, että Smallwoodin käsitys "autenttisesta" newfoundilaisesta kulttuurista tarkoitti pääasiassa eurooppalaisten uudisasukkaiden perintöä. Provinssissa edelleen asuvien inuiittien, innujen ja mi'kmaq -alkuperäiskansojen kulttuuriperintö ei saanut osakseen samanlaista huomiota. Muualla Kanadassa sitä pyrittiin systemaattisesti hävittämään Kanadan hallituksen luomassa sisäoppilaitosjärjestelmässä, johon alkuperäiskansojen lapsia pakotettiin vuoteen 
1996 asti. Newfoundlandissa sisäoppilaitoksia ei koskaan ollut, koska provinssin liittyessä Kanadaan pääministeri Smallwood väitti, ettei Newfoundlandilla ollut alkuperäiskansojen jäseniä, jottei joutuisi kunnioittamaan näiden maaoikeuksia.

\section{Uusia suuntauksia}

Ennen saapumistani paikallisessa folkloristiikan oppiaineessa kävi laaja eläköitymisaalto, jonka seurauksena aikaisemmin pääasiassa vanhojen valkoisten miesten hallitsema henkilökunta on muuttunut moniulotteisemmaksi niin sukupuoli- ja ikäjakaumansa kuin tutkimusaiheidensakin osalta. Tohtorit ovat pääasiassa Yhdysvalloista ja Kanadasta, mutta myös Eurooppa on edustettuna Skotlannin ja Ukrainan osalta. Maisteri- ja jatko-opiskelijat ovat taustaltaan monikulttuurinen ja -alainen ryhmä, jossa olen kandista asti folkloristiikassa opintoja suorittaneena harvinaisuus. Kanssaopiskelijoilla on takanaan tutkintoja niin kirjallisuudesta kuin kauppatieteistäkin. Erikoisuutena on mainittava tarjolla oleva kaksiväyläinen maisterintutkinto, jossa opiskelija joko kirjoittaa lopputyönään gradua vastaavan opinnäytteen tai tekee kolme työharjoittelujaksoa. Jälkimmäinen public folklore -väylä on tarkoitettu opiskelijoille, jotka haluavat suoraan työelämään tutkintonsa jälkeen, ensimmäinen taas vastaa perinteistä maisterin tutkintoa. Tutkimuksen kohteiden puolesta osa henkilökunnasta painottaa melko vahvasti aineellista perinnettä, etenkin käsitöitä ja ruokaa. Yhtenä esimerkkinä tässä mainittakoon professori Diane Tye, jonka teos Baking as Biography - $A$ Life Story as Recipes (2010) on voittanut Elli Köngäs-Maranda -kirjapalkinnon. Siinä Tye tutkii äitinsä reseptejä elämäkertana. Henkilökunnan ruokaa koskevan tapakulttuurin ymmärrys on hyödyttänyt myös omaa huumeisiin liittyvää tutkimustani. Samat metodit, joita perinteisesti sovelletaan ruoan kasvatuksen, valmistuksen ja kulutuksen tutkimuksessa, ovat melko helposti sovellettavissa myös huumeiden tapakulttuuriin. Edustamaani epävirallisten ekonomioiden (engl. informal economies) tutkimusta edustavat ohjaajani Cory Thorne, havannalaisen seksikaupan ja afrokuubalaisen santeria-uskonnon asiantuntija (ks. Thorne 2019), sekä John Bodner, jonka työ rikollisten kommunikaatiotekniikoiden parissa (Bodner 2019) on ollut minulle valtavan hyödyllistä.

Vuoden 2020 alku antoi St. Johns'in kaupungille esimakua koronaviruksen myöhemmin globalisoimasta eristäytymisestä. Poikkeuksellinen lumisade ja hurrikaani peittivät kaupungin viikoksi 80 sentin mittaiseen lumikerrokseen tuulen puhaltaessa yli sata kilometriä tunnissa. Tuhannet menettivät sähköt useaksi päiväksi, pormestari julisti ulkonaliikkumiskiellon ja armeija kutsuttiin paikalle raivaamaan lunta kaduilta. Snowmageddoniksi ristitty myrsky toi esiin ne kaksi Newfoundlandin piirrettä, jotka mainitsen aina kun minulta kysytään, mitä pidän täällä asumisesta. Vastaan: "The weather is terrible, but the people are lovely." Opintojen jatkaminen ulkomailla on ollut monella tapaa vaikeaa, mutta uskon sen myös tehneen minusta sitkeämmän ihmisen. Kävi valmistumisen jälkeen miten tahansa, tiedän, että selviän tästedes mistä vain. Loppukaneettina mainittakoon, että palatessani viime kesänä Italiasta konferenssista jouduin jäämään vuorokaudeksi Frankfurtiin Kanadan itärannikkoa raadelleen hurrikaanin vuoksi. Lisäjännitystä aiheutti Kanadaan unohtamani opiskelijaviisumi, jonka puuttumisen pilkuntarkat saksalaiset uskoivat tarkoittavan että minut käännytettäisiin takaisin. Laskeuduttuani tällä puolella Atlanttia kävelin lakki kourassa paikallisen rajavartijan tiskille ja selitin tilanteeni. Vastaukseksi sain hyvin kevyen nuhtelun ja muistutuksen oikeiden matkustusdokumenttien tärkeydestä ja lähtiessäni vielä iloisen "Moi moi!":n, jonka vartija oli oppinut katsoessaan suomalaista tv:tä. 


\section{Lähdeluettelo}

Bodner, John. 2019. "The Speaking Body and the Silent Mouth - Communication Techniques and Tactics in Criminal Activities and Occupations." Ethnologies 41 (1), 247-265. https:// doi.org/10.7202/1069854ar

Thorne, Cory W. 2019. "Creating Something out of Nothing - Food, Sex, and Housing in Havana's Underground Economies." Ethnologies 41 (1), 267-287. https://doi. org/10.7202/1069855ar

Tye, Diane. 2010. Baking as Life - A Life Story in Recipes. Montreal: McGill - Queens's University Press.

Virratvuori, Akseli. 2018. Kannabiksen käyttäjä suvaitsevaisuuden kynnyksellä: Suomalainen ritualisoitu kannabiksen käyttö siirtymäriittinä. Pro gradu -tutkielma Turun yliopistossa. https://www.utupub.fi/handle/10024/144481.

Filosofian maisteri Akseli Virratvuori on folkloristiikan jatko-opiskelija Kanadassa (Department of Folklore, Memorial University of Newfoundland). Hänet voi tavoittaa sähköpostilla aavirratvuor@mun.ca tai akseli.virratvuori@gmail.com Kanadassa opiskeluun, huumekulttuuriin tai oikeastaan mihin tahansa liittyvin kysymyksin ja kommentein. 